\title{
Feeding of Acestrorhynchus lacustris (Characidae): A Post Impoundment Studies on Itaipu Reservoir, Upper Paraná River, PR
}

\author{
Norma Segatti Hahn ${ }^{1^{*}}$, Rosilene Luciana Delariva ${ }^{2,3}$ and Valdirene Esgarbosa Loureiro ${ }^{2}$ \\ ${ }^{1}$ Universidade Estadual de Maringá/DBI/Núcleo de Pesquisas em Limnologia Ictiologia e Aquicultura (Nupélia), \\ Av. Colombo, 5790 Bloco G-90. Cep: 87.020-900. Maringá - PR. ${ }^{2}$ Pós-graduação em Ecologia de Ambientes \\ Aquáticos Continentais PEA, Av. Colombo, 5790 Bloco G-90. Cep: 87.020-900. Maringá - PR.. ${ }^{3}$ Universidade \\ Paranaense/UNIPAR, Umuarama/Toledo - PR.
}

\begin{abstract}
With objective to know feeding spectrum of Acestrorhynchus lacustris (Reinhardt, 1874), a middle size predator in different places of influence area of Itaipu reservoir, stomach contents were analyzed. Samples were collected from March 1984 to February 1989 from Itaipu Reservoir and its adjacent areas. Its fed mainly on fishes, but it was an opportunistic (consumed 17 species of prey). Despite of the wide feeding spectrum, few preys were dominant in the diet, according to the different habitats sampled. As a result, it significant spatial differences in the diet was observed. Was observed through "Detrented Correspondence Analysis" (DCA) these were divided into three groups in relation with diet: preys from upstream, with higher scores; preys from the reservoir, with intermediate scores; and preys from a tributary with smaller scores. This discrimination may be a function of prey availability in each habitat. The mean size of preys consumed increased with the size of the predator, as well as the variance, $i$. e. the largest fish also consumed small preys.
\end{abstract}

Key words: Feeding, Predation, Characidae, Upper Paraná River, Itaipu Reservoir

\section{INTRODUCTION}

Acestrorhynchus lacustris (Reinhardt, 1874) is a characid of the subfamily Acestrorhynchinae, commonly known as the "peixe cachorro" or "bicuda". It is a medium-sized fish, and in the region of the Itaipu Reservoir is considered a fourth-class fish, of little commercial value. It is occasionally recorded in the commercial fishery. In experimental fishing it has been rarely caught in the riverine region, but more often in the lacustrine region. In spite of the low commercial value, the role of A. lacustris in the food chain must be fundamental. Besides serving as food for the large predators, it is a known piscivore which must act to control the fodder species, which become very abundant in the first years of formation of a reservoir (Agostinho et al., 1992). Fish with this type of feeding habit increase the stability of an ecosystem, since they regulate the abundance of prey species (Nikolsky, 1963; Popova, 1978). Studies of trophic ecology serve to support these suppositions, since the food spectra of fishes reflect the role of each in the ecosystem. Studies on the feeding of A. lacustris are limited to those of Catella \& Torres (1984) in Três Marias Reservoir, State of Minas Gerais; Mesquiatti (1995) in an oxbow lake of the Mogi-Guaçu River, State of São Paulo; and Almeida et al. (1997) in the floodplain of the Upper Paraná River, State of Paraná. Trophic studies of large ichthyofaunistic communities have made brief reference to this species or others of the same genus (Barthem, 1987; Meschiatti, 1995; Benneman, 1996; Resende et al., 1996; Hahn et al., 1997). This paper describes the diet of A. lacustris in the area influenced by Itaipu Reservoir, the spacial and annual variations of the diet, its degree of overlap and the relationships between predator and prey sizes.

\section{MATERIALS AND METHODS}

The samples were taken in the Paraná River basin, in the area influenced by Itaipu Reservoir (Fig. 1).

\footnotetext{
* Author for correspondence
} 
The collection points included the reservoir (Guaíra, Santa Helena, and Foz a tributary (the São Francisco Falso River), and upstream (the Iguatemi and Piquiri Rivers). Itaipu Reservoir was closed in 1982, and collections of fish were begun in 1984. Collections were made monthly from March 1984 through February 1985, and bimonthly from March 1985 through February 1989. In the present study, because of the absence of this species from catches during certain periods and the common occurrence of specimens with empty stomachs, more detailed analysis was not possible.

The fish were caught with stationary nets of different mesh sizes (3.0 to $16.0 \mathrm{~cm}$ between adjacent knots). After the specimens were captured and measured, the stomachs were removed and preserved in $4 \%$ formol. This stomachs were analyzed after each sample.
The gastric contents were analyzed by the occurrence and gravimetric methods, combined in the Alimentary Index modified (IAi) (Kawakami \& Vazzoler, 1980). The similarity between the diet of the prey organisms was evaluated by Spearman's Correlation. Bonferroni's Correlation (= $0.05 /$ number of tests) was used to evaluate the significance of the tests (Cristensen, 1996).

The combination of environment with season of collection was ordinated according to the food items consumed by A. lacustris, using Detrended Correspondence Analysis (DCA; Jongman et al., 1995). The data for diet obtained by application of the IAi were used in this ordination.

The relationship between the size of the predator (A. lacustris) and the prey was established based on the standard lengths of both in centimeters.

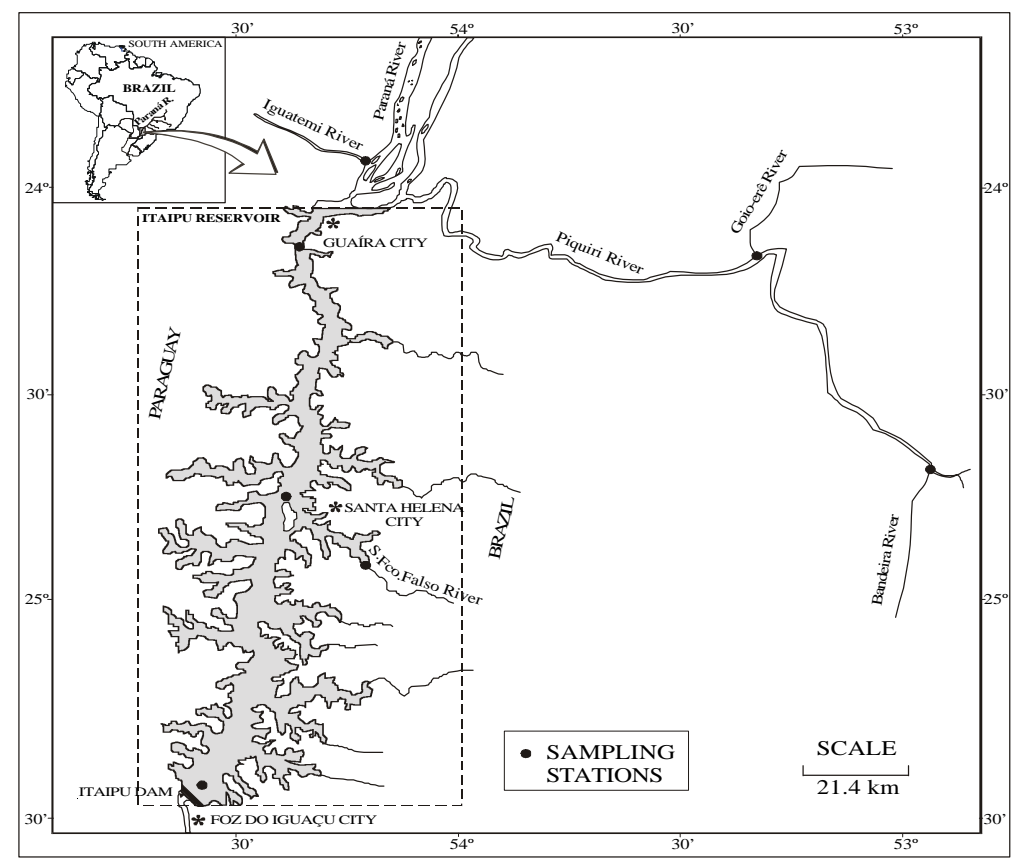

Figure 1 - Geographic location of the area studied. Square indicates the area influenced by Itaipu Reservoir.

\section{RESULTS}

Analysis of the stomach contents of 83 adult individuals of the A. lacustris (Ls 10.7-29.7 cm) showed that this species fed exclusively on fish in the different habitats sampled. The food spectrum showed 17 species of prey fish, and others which could not be identified because of the advanced state of digestion (Table 1). In spite of the large variety of prey recorded, few species stood out in each environment. The alimentary index showed that in the reservoir these species were prominent, in decreasing order of importance: Astyanax bimaculatus (35.6\%), Crenicichla niederleinii (29.4\%), and Steindachnerina insculpta (20.6\%). In the tributaries, the most important prey species were Crenicichla niederleinii (35.8\%), Astyanax bimaculatus (27.1\%), and Prochilodus lineatus (22.7\%). Upstream, Bryconamericus stramineus composed practically the entire diet (73.8\%) 
(Table I). Although several prey species were common in all three environments, there was no significant correlation indicating differences in the diet of the fish between the reservoir and tributary $(\mathrm{S}=0.1756 ; \mathrm{p}=0.4721)$, reservoir and upstream
$(\mathrm{S}=0.1154 ; \mathrm{p}=0.6380)$, and tributary and upstream $(\mathrm{S}=0.1451 ; \mathrm{p}=0.5533)$. However, we noted the small number of stomachs examined from fish caught in the tributary.

Table 1 - Relative frequency of occurrence (\% O), weight (\% W), and Alimentary Index (\% IAi) for prey items of Acestrorhynchus lacustris in the different environments sampled.

\begin{tabular}{|c|c|c|c|c|c|c|c|c|c|}
\hline \multirow[b]{2}{*}{ Preys } & \multicolumn{3}{|c|}{ Reservoir $(\mathrm{n}=36)$} & \multicolumn{3}{|c|}{ Tributary $(n=7)$} & \multicolumn{3}{|c|}{ Upstream (n=40) } \\
\hline & $\% \mathbf{O}$ & $\% \mathrm{P}$ & \% IAi & $\% 0$ & $\% \mathbf{P}$ & $\%$ IAi & $\% 0$ & $\% \mathbf{P}$ & $\%$ IAi \\
\hline Apareiodon affinis & & & & & & & 2,44 & 0,43 & 0,07 \\
\hline Astyanax bimaculatus & 13,51 & 35,84 & 35,63 & 14,29 & 35,62 & 27,13 & 4,88 & 8,98 & 2,72 \\
\hline Astyanax fasciatus & & & & 14,29 & 7,85 & 5,98 & 4,88 & 10,18 & 3,08 \\
\hline Bryconamericus stramineus & & & & & & & 46,34 & 25,68 & 73,85 \\
\hline Characidium $\mathrm{sp}$ & 2,71 & 0,19 & 0,04 & & & & & & \\
\hline Crenicichla lepidota & & & & 14,29 & 11,03 & 8,4 & & & \\
\hline Crenicichla niederleinii & 16,22 & 24,66 & 29,4 & 42,85 & 15,67 & 35,78 & 9,76 & 15,91 & 9,64 \\
\hline Crenicichla haroldoi & & & & & & & 2,44 & 2,79 & 0,42 \\
\hline Hyphessobrycon callistus & 13,51 & 1,31 & 1,3 & & & & 2,44 & 0,74 & 0,11 \\
\hline Leporinus amblirhynchus & & & & & & & 2,44 & 8,32 & 1,26 \\
\hline Miloplus sp & & & & & & & 2,44 & 2,85 & 0,42 \\
\hline Moenkhausia intermedia & 21,62 & 3,63 & 5,77 & & & & 7,31 & 2,91 & 1,32 \\
\hline Piabina argentea & & & & & & & 7,31 & 12,91 & 5,86 \\
\hline Prochilodus lineatus & & & & 14,29 & 29,83 & 22,71 & & & \\
\hline Roeboides paranensis & 13,51 & 6,92 & 6,88 & & & & 2,44 & 0,89 & 0,13 \\
\hline Serrasalmus marginatus & 2,71 & 0,28 & 0,05 & & & & & & \\
\hline Steindachnerina insculpta & 10,81 & 25,94 & 20,64 & & & & 2,44 & 6,65 & 1,01 \\
\hline Peixe não identificado & 5,42 & 1,23 & 0,24 & & & & & & \\
\hline Tetragonopterinae & & & & & & & 2,44 & 0,76 & 0,11 \\
\hline
\end{tabular}

$\square$ Principal preys

The results of the spatio-temporal ordination of the diet by correspondence analysis are shown in Fig. 2. The first axis (eigenvalue $=0.93$ ) grouped the majority of localities and years in the lowest scores, and segregated the diet of A. lacustris in the reservoir/1996, as a result of high consumption of Hyphessobrycon callistus and Moenkhausia intermedia. The second axis (eigenvalue $=0.64$ ) was the most representative. This axis separated the upstream with higher values, mainly because of the ingestion of B. stramineus; the reservoir with intermediate values, represented mainly by the prey species $A$. bimaculatus and $C$. niederleinii; and tributaries with the lowest values, because of ingestion of $C$. niederleinii and $P$. lineatus. This analysis, however, showed that diet is differentiated mainly as a function of environment, not of year of collection.

The relationship between the length of the predator is showed in figure 3 and its prey $[y=-964683( \pm$ $0,678283)+0,346256( \pm 0,040270)]$. Note that as A. lacustris grows, the prey taken increase in size $\left(\mathrm{r}^{2}\right.$ 0,4589). Nevertheless, we observe from the dietary composition that even specimens approximately $20.0 \mathrm{~cm}$ long consume small-sized prey. 

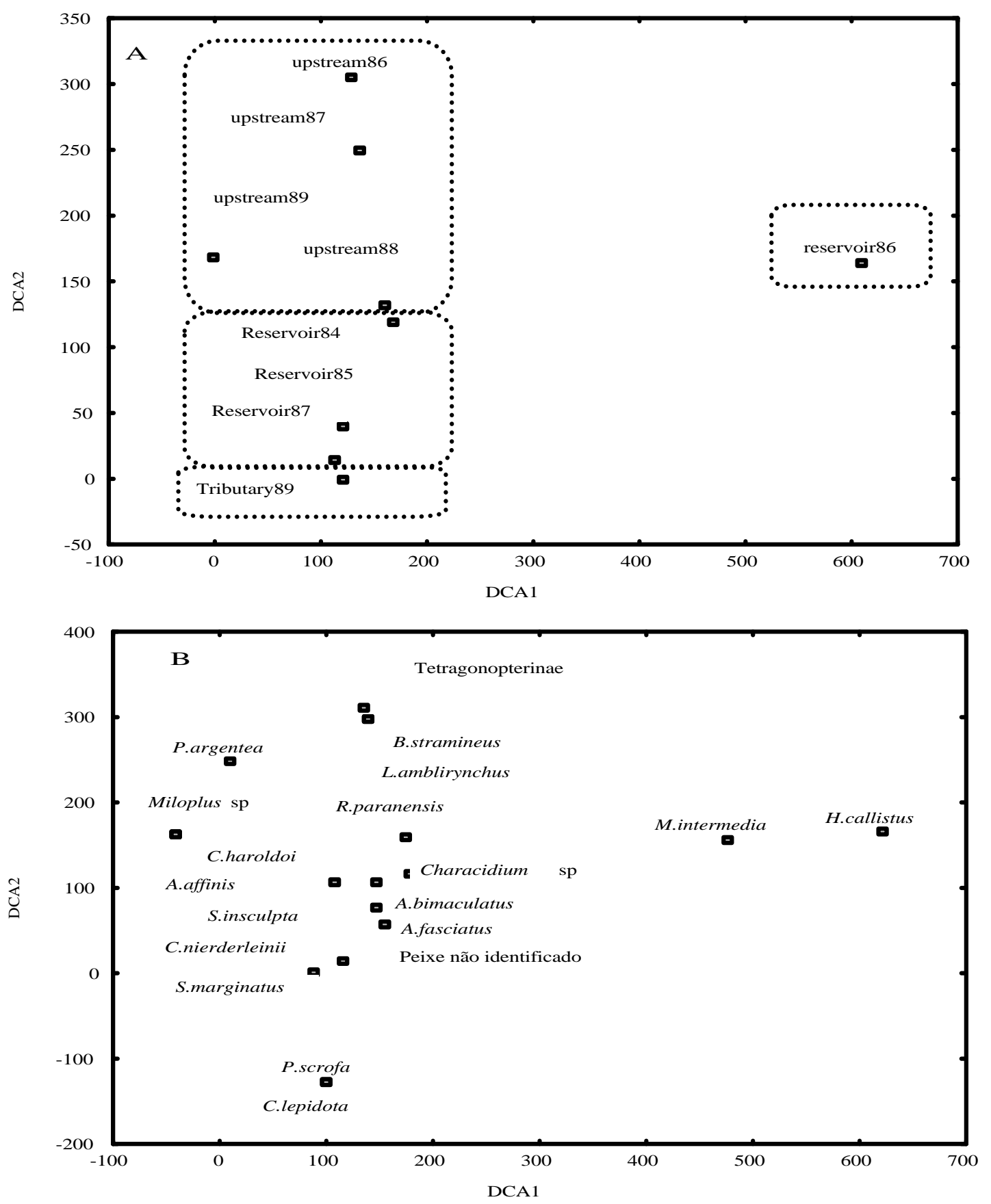

Figure 2 - Graphical representation of the space defined by the first two DCA axes, based on the IAi data for Acestrorhynchus lacustris. A, ordination of the localities and seasons. B, ordination of prey items. 


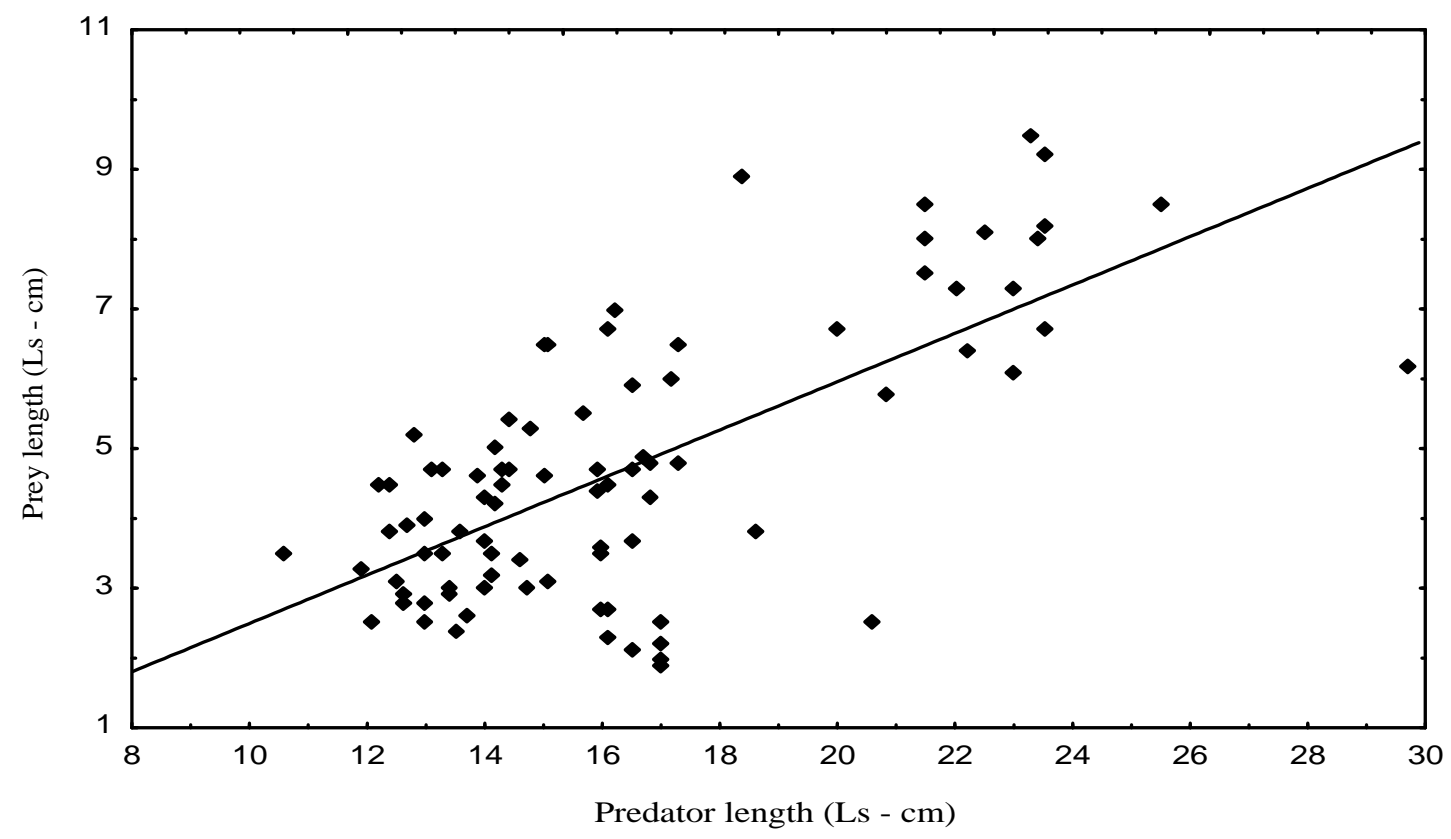

Figure 3 - Relationship between the sizes of the predator, Acestrorhynchus lacustris, and its prey species.

\section{DISCUSSION}

In the Itaipu Reservoir region, specimens of $A$. lacustris over $10.0 \mathrm{~cm}$ had an exclusively piscivorous diet. Our studies corroborated those of Benneman et al., (1996), who found only fish in the stomach of this species in the Tibagi River, State of Paraná. In other studies of its diet, insects and plants were also recorded, though only as occasional food (Catella \& Torres, 1984; Mesquiatti, 1995; Almeida et al., 1997; Benneman, 1996). It is obvious, however, that the wide spectrum of prey fish characterizes it as an opportunistic species (Gerking, 1994). In the Pantanal of the Mato Grosso, another species of this genus, Acestrorhynchus pantaneiro, although it consumed fish, also consumed practically an equal proportion of shrimp (Resende, 1996). The main prey species composing the diet in the three environments studied were small fodder species, which requently inhabited the littoral zones of waterbodies (Delariva et al., 1994; Benneman, 1996). Acestrorhynchus lacustris must follow the movements of these prey species, since its canine and conical teeth and prognathous mouth facilitate predation at the water surface. Nico \& Taphorn (1985) referred to Acestrorhynchus microlepis as an active species which inhabits nearshore areas in the llanos of Venezuela. The composition of food showed no correlation between the environment, doubtless as a result of the abundance of certain prey species in the localities sampled. Wootton (1990) referred to fish as good samplers and emphasized that the stomach contents reflect what is available in the environment. Hahn et al. (1997) verified this fact for the piscivorous species Plagioscion squamosissimus in Itaipu Reservoir, where it feeds intensively on two species of fish which became very abundant soon after closure of the reservoir. On the Upper Paraná River floodplain, Almeida et al. (1997) established that five species of piscivorous fish, including $A$. lacustris, showed themselves to be opportunists in relation to prey abundance, taking advantage of the seasonal offerings of the environment. According to Graham \& Vrijenhoek (1988), ordination of food items along the DCA axes shows a distribution of the prey and of the behavior of the predators. In the present study, three spatial groups were formed as a function of food type: upstream, reservoir, and tributaries. However, the annual data (season in which the predator was collected) did not influence the analysis, since the diversity and abundance of these fodder species varied little during those years (Benedito-Cecílio, 1994). In view of this, we could infer that the characteristics of the environments studied, mainly those of the reservoir, did not undergo relevant changes. Prey size is a limiting factor for the predator, because of the capacity of 
the mouth opening and often the size of the stomach. Several investigators have observed that piscivores ingest prey smaller than one-third of their own length (Goulding et al., 1988; MachadoAllison, 1990; Almeida et al., 1997). However, this is not a rule, since the traíra Hoplias malabaricus, as reported in a number of studies, can ingest fish nearly its own length (Barthem, 1987; Winemiller, 1989; Almeida, 1994; Loureiro \& Hahn, 1996). In the present study, the largest prey recorded was a specimen of Crenicichla niederleinii $9.5 \mathrm{~cm}$ long, eaten by an individual $23.3 \mathrm{~cm}$ long. However, most prey individuals were between 3.0 and $5.0 \mathrm{~cm}$. These data corroborate those of Catella \& Torres (1984) in Três Marias Reservoir and of Almeida et al. (1997) on the Parana River floodplain, for the same species.

\section{CONCLUSIONS}

At present, A. lacustris is not being caught in the area of the Itaipu Reservoir, either by professional fishermen or in experimental fishing. At the same time Hoplias malabaricus, Raphiodon vulpinus, and the introduced species Cichla ocelaris have substantially increased their populations. It is probable that because of intense competition from these piscivores together with other factors that have not been investigated, A. lacustris has become drastically less abundant in this environment.

\section{ACKNOWLEDGEMENTS}

We thank Itaipu Binacional for financial support, Nupelia (Center for Research in Limnology, Ichthyology, and Aquaculture) for infrastructural support. Janet W. Reid translated the text into English.

\section{RESUMO}

Com o objetivo de conhecer o espectro alimentar de Acestrorhynchus lacustris (Reinhardt, 1874), um predador de médio porte, em diferentes locais da área de influência do reservatório de Itaipu, foram analisados conteúdos estomacais coletados no período de março/84 a fevereiro/89. Os dados evidenciaram tratar-se de uma espécie exclusivamente piscívora, porém oportunista, visto que consumiu 17 espécies de peixes-presa. Apesar do amplo espectro alimentar, poucas presas se destacaram nos distintos ambientes amostrados, resultando em diferenças significativas entre suas dietas. A análise de correspondência (DCA) discriminou espacialmente três grupos; montante, com maiores escores; reservatório, com valores intermediários e tributário com menores valores, provavelmente em função dos tipos de presas disponíveis em cada ambiente. $\mathrm{O}$ tamanho das presas ingeridas aumenta com o crescimento do predador, porém os maiores exemplares não descartam peixes de pequeno porte de sua dieta.

\section{REFERENCES}

Agostinho, A. A. (1992), Manejo de recursos pesqueiros em reservatórios. In: Situação Atual $e$ Perspectivas da ictiologia no Brasil, eds. A.A. AGOSTINHO \& E. BENEDITO-CECÍLIO. Documento do IX Encontro Brasileiro de Ictiologia EDUEM, Nupélia, Maringá PR, pp. 106-121

Almeida, V. L. L. (1994), Utilização de recursos alimentares por peixes piscívoros da planície de inundação do Alto rio Paraná $\left(22^{\circ}\right.$ 40'$\left.22^{\circ} 50^{\prime} \mathrm{S} / 53^{\circ} 40^{\prime} \mathrm{W}\right)$, Brasil. UEM, Maringá, 1994, 30p. Dissertação Mestrado, Universidade Estadual de Maringá, Maringá-Paraná, Brasil

Almeida, V. L. L, Hahn, N. S. \& Vazzoler, A. E. A. de M. (1997), Feeding patterns in five predatory fishes of the high Paraná river floodplain (PR, Brazil). Ecol. Fresh. Fish., 1007 (6), 123-133.

Barthem, R. B. (1987), Uso de redes de espera no estudo de ritmos circadianos de algumas espécies de peixes nos lagos de várzea do rio Solimões. Rev. Bras. Zool., 3 (7), 409-422.

Benedito-Cecílio, E. (1994), Dominância, uso do ambiente e associações interespecíficas na ictiofauna do reservatório de Itaipu e alterações decorrentes do represamento. UFSCar, São Carlos, 1994, 173p. Tese Doutoramento, Universidade Federal de São Carlos, São Carlos, São Paulo

Benneman, S. T. (1996), Dinâmica trófica de uma assembléia de peixes de um trecho do rio Tibagi (Sertanópolis- Paraná). UFSCar, 1996, 144p. Tese Doutoramento, Universidade Federal de São Carlos, São Carlos, São Paulo

Benneman, S. T., Orsi, M. L. \& Shibatta, O. A. (1996), Atividade alimentar de espécies de peixe do rio Tibagi, relacionada com o desenvolvimento de gordura e das gônadas. Rev. Bras. Zool., 13.(2), 501512 
Catella, A. C. \& Torres, G. E. (1984), Observações sobre o espectro e estratégias alimentares do peixecachorro, Acestrorhynchus lacustris (Reinhardt, 1874) (Characidae, Acestrorhynchini), no reservatório de três Marias - Rio São Francisco, MG. In Seminário Regional de Ecologia de São Carlos, 14. Anais... São Carlos: Universidade Federal de São Carlos, pp. 103-125

Cristensen, R. (1996), Analysis of variance, design and regression: applied statistical methods, Chapman \& Hall, London, 587p

Delariva, R. L., Agostinho, A. A., Nakatani, K. \& Baumgartner, G. (1994), Ichthyofauna associated to aquatic macrophytes in the upper Parana River floodplain. Rev. Unimar, Maringá, 16 (Supl. 3), 4160

Gerking, S. D. (1994), Feeding ecology of fish, Academic Press, San Diego, 416p

Goulding, M., Carvalho, M. L. \& Ferreira, E. G. (1988), Rio Negro, rich life in poor water Amazon diversity and food chain ecology as seen through fish communities. SPB Academic Publishing, The Hague, $200 \mathrm{p}$

Graham, J. \& Vrijenhoek, R. C. (1988), Detrended correspondence analysis of dietary data. Trans. Amer. Fish. Soc., 177, 29-36

Hahn, N. S., Agostinho, A. A. \& Goitein, R. (1997), Feeding ecology of curvina Plagioscion squamosissimus (Hechel, 1840) (Osteichthyes, Perciformes) in the Itaipu reservoir and Porto Rico Floodplain, Acta Limnol. Brasil, 9, 11-22

Jongman, R. H. G., Braak, T. \& Van Tongeren, O. F. R. (1995), Data analysis in community and landscape ecology. Cambridge University Press, Cambridge, $299 \mathrm{p}$

Kawakami, E. \& Vazzoler, G. (1980), Métodos gráfico e estimativa do índice alimentar aplicado no estudo de alimentação de peixes. Bol. Inst. Oceonog., 29 (2), 205-207

Loureiro, V. E. \& Hahn, N. S. (1996), Dieta e atividade alimentar da traíra, Hoplias malabaricus (Bloch, 1794) (Osteichthyes, Erythrinidae), nos primeiros anos de formação do reservatório de Segredo - PR., Acta Limnol. Brasil., 8, 195-205

Machado-Allison, A. (1990), Ecologia de los peces de las areas inundables de los llanos de Venezuela. Interciência, 15 (6), 411-423

Mesquiatti, A. J. (1995), Alimentação da comunidade de peixes de uma lagoa marginal do rio Mogi-Guaçu, SP. Acta Limnol. Brasil., 7, 115-137

Nico, L. G. \& Taphorn,D. C. (1985), Diet of Acestrorhynchus microlepis (Pisces: Characidae) in the low llanos of Venezuela. Copeia, 3, 794-796

Nikolsky, G. V. (1963), The ecology of fishes. Academic Press, London, 352p

Popova, O. A. (1978), The role of predaceous fish in ecosystems. ed. S. D. GERKING. Ecol. Fresh. Fish Production,. Blackwell Scientific, Oxford, pp. 215249

Resende, E. K., Pereira, R. A. C., Almeida, V. L. L. \& Silva, A. G. (1996), Alimentação de peixes carnívoros da planície inundável do rio Miranda, Pantanal, Mato Grosso do Sul, Brasil. EMBRAPACPAP, Corumbá, MS, 1996, 36p. (EMBRAPACPAP. Boletim de Pesquisa; 03)

Winemiller, H. O. (1989), Patterns of variation in life history among South American fishes in seasonal enviroments. Oecologia, 81, 225-241.

Wootton, R. J. (1990), Ecology of teleost fishes. Chapman \& Hall, London; New York, 404p.

Received: January 21, 1999; Revised: May 09, 1999; Accepted: November 21, 1999. 